\title{
A Case Report: Management of Granular Pharyngitis with Ayurveda
}

\author{
Case Report
}

\section{Jetal Gevariya ${ }^{*}$, Bhoomi Mehta1, Vaghela DB2}

\author{
1. PG Scholar, 2. I/C HOD \& Associate Professor
}

Department of Shalakya Tantra, ITRA, GAU, Jamnagar, Gujarat, India.

\begin{abstract}
Background: Granular pharyngitis is an acute or subacute form of throat disease which is extremely common in autumn and spring. It is characterized by marked swelling of the follicular tissue of the pharynx, which has a granular glazed appearance. Symptomatically it can be correlated with Kaphaja Rohini or Kanthashalooka. Methods: A 20-year-old patient presented with complaint of recurrent dry cough, rhinorrhea, dysphagia, dry and sore throat, tiredness of voice since last 4 months. Management done with OPD based treatment. here in this case report treatment chosen was i.e. Yashtimadhu Ghanavati, Shitopaladi Churna, Naradiya Laxmi Vilasa Rasa Orally, Dashamoola Kwatha (Kavala), Yashtimadhu Churna (Pratisarana). Result: There was marked improvement in symptoms like recurrent dry cough, rhinorrhea, dysphagia, dry and sore throat tiredness of voice with the treatment of 1 month. Conclusion: Significant result was observed with this treatment protocol in the management of granular pharyngitis.
\end{abstract}

Key Words: Ayurveda, Dry cough, Granular pharyngitis, Kanthashalooka, Kaphaja Rohini.

\section{Introduction}

Chronic granular pharyngitis is characterized by an alteration in the mucous membrane of the pharynx involving the mucous glands and the lymph follicles. The initial stage of hyperemia is followed by inflammatory changes in the connective tissue and the hyperplasia of lymphoid follicles. The granulations are made up of masses of lymphoid cells, grouped around the mouths of the ducts of the mucous glands, variation in the size of granulations person to person (1). Mucous membrane of oropharynx is highly vascularized and innervated. It has the double load of transmitting air and food and is subjected to infections and trauma by way of the mouth as well as the nose and nasopharynx. Granular pharyngitis occurs due to persistent infection in the neighborhood i.e. chronic irritants to the pharynx i.e. excessive smoking, highly spiced food etc., smoky and dusty environment, industrial/occupational irritants, persistent infection in the neighborhood i.e. chronic rhinitis and sinusitis (2), mouth breathing, and faulty voice production (3). Symptoms are sore throat, dysphagia, foreign body sensation in throat, dry cough and tiredness of voice. In Ayurvedic literature Acharya Sushruta has described seventeen diseases occuring in Kanthapradesh. Symptomatically granular pharyngitis

* Corresponding Author:

\section{Jetal Gevariya}

PG Scholar,

Department of Shalakya Tantra,

IPGT \& RA, GAU,

Jamnagar, Gujarat, India

Email Id: dr.jetalgevariya007@gmail.com can be correlated with Kaphaja Rohini and Kanthashalooka. In case of Kaphaja Rohini the vitiated Kapha Dosha causes a Sthira (immobile), Gurvi (bulky), Srotonirodhi (obstructing swelling in throat which cause dysphagia) swelling of the throat (4). Acharya Sushruta mentioned its line of treatment as Pratisarana, Nasya and Kavaladharana with various formulations (5). Kanthashalooka occurs due to vitiation of Kapha Pradhana Tridosha and site of presentation is Gala Pradesh (Throat), leads to Kolashthimatra(size of jujube seed), Khara(rough), Sthira (immobile) Granthi in throat, which causes pain like Kantakas (sore throat) (6). According to Acharya Vagbhatta it is treated with the same treatment of Kaphaja Rohini.

\section{Case Report}

A 20-years-old patient presented with complaint of recurrent dry cough, rhinorrhea, severe dysphagia, dry and sore throat since last 4 months at Shalakya Tantra (ENT) OPD of IPGT \& RA hospital, GAU, Jamnagar on date 18/1/2020. Patient was suffering from aggravation of the same complaints in spring and autumn season since last 4 years and feels temporary relief by Gargles with Luke warm saline water.

\section{History of present illness}

Patient was apparently normal before four years. Gradually patient suffered with rhinorrhea, dry cough, dry and sore throat, dysphagia and tiredness of voice. For that patient approached contemporary medical sciences for treatment and using lozenges and NSAIDS drugs with only temporary relief in dry, sore throat and dry cough. But patient's complaints did not get satisfactory result and complaints were aggravated 
Jetal Gevariya et.al., A case report: Management of Granular Pharyngitis with Ayurveda

in every spring and autumn season for 4 years. Patient was suffering from allergy of flower dust and smoke from last 4 years. So, patient came to our hospital, and was treated with Yashtimadhu Ghanavati, Shitopaladi Churna, Naradiya Laxmi Vilasa Rasa Orally, Dashamoola Kwatha (Kavala), Yashtimadhu Churna (Pratisarana). No other past history was noted according to patient statement.

\section{Personal History}

Diet: Vegitarian, Appetite: Moderate, Bowel: Regular (1 time/ day), Micturition: Normal (5-6 time/ day), Sleep: Disturbed, Addiction: Tea (2 times/day), Smoking (1 time /day)

\section{Occupational History}

Engineering.

Patient is studying diploma course in IT

\section{Diagnosis}

When patient came to OPD of Shalakya Tantra, oropharynx was examined and after that telescopy done, patient was diagnosed as granular pharyngitis. After assessing the causes and symptoms, Ayurvedic diagnosis was made "Kaphaja Rohini".

\section{$\mathbf{O} / \mathbf{E}:$}

The following were observed:

- Nose: Pale nasal mucosa

- Ear: No any abnormality found

- Throat: Anterior pillars: Congested

- Tonsils: Normal

- Posterior pillars: Congested

- PPW: Swelling of the follicular tissue, which has a granular glance appearance

\section{Figure 1: Before treatment granular pharyngitis}

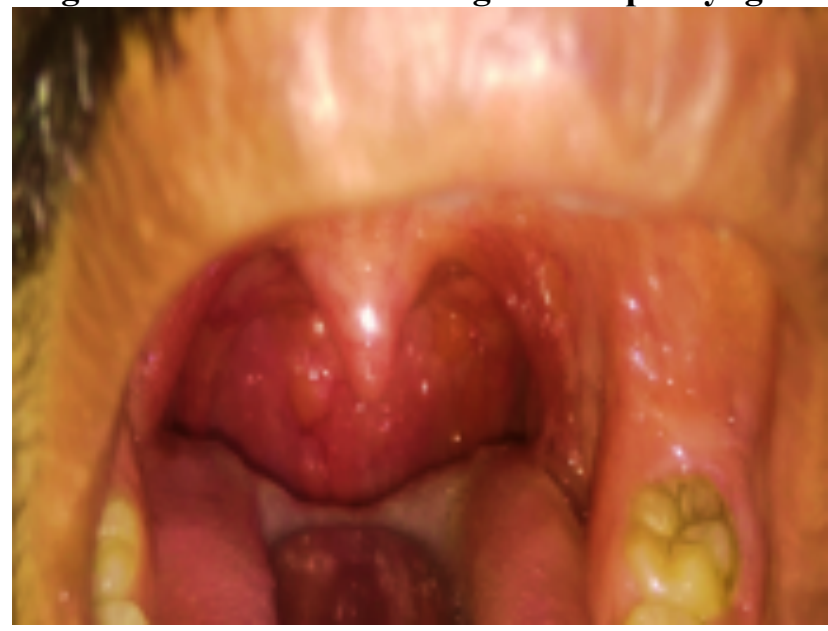

Therapeutic Intervention: See table no. 1 Table 1: Treatment protocol

\begin{tabular}{|c|c|c|c|}
\hline Drug & Dose & $\begin{array}{l}\text { Root of } \\
\text { administr } \\
\text { ation }\end{array}$ & Duration \\
\hline $\begin{array}{l}\text { Yashtimadhu } \\
\text { Ghanavati }\end{array}$ & $\begin{array}{l}\text { One tablet } \\
\text { four time } \\
\text { in a day }\end{array}$ & $\begin{array}{l}\text { Chewing } \\
\text { (Chusana } \\
\text { rtha) }\end{array}$ & 1 month \\
\hline
\end{tabular}

\begin{tabular}{|l|l|l|l|}
$\begin{array}{l}\text { Shitopaladi } \\
\text { Churna }\end{array}$ & $\begin{array}{l}\text { 3 gm BD } \\
\text { with } \\
\text { Madhu }\end{array}$ & Orally & 1 month \\
\hline $\begin{array}{l}\text { Naradiya } \\
\text { Laxmi Vilasa } \\
\text { Rasa }\end{array}$ & $\begin{array}{l}250 \mathrm{mg} \\
\text { BD with } \\
\text { Madhu }\end{array}$ & Orally & 1 month \\
\hline $\begin{array}{l}\text { Dashamoola } \\
\text { Kwatha }\end{array}$ & $\begin{array}{l}\text { Two times } \\
\text { in a day }\end{array}$ & $\begin{array}{l}\text { Gargling } \\
\text { (Kavala) }\end{array}$ & 1 month \\
\hline $\begin{array}{l}\text { Yashtimadhu } \\
\text { Churna }\end{array}$ & $\begin{array}{l}\text { 3 gm BD } \\
\text { with } \\
\text { Madhu }\end{array}$ & $\begin{array}{l}\text { Local } \\
\text { applicatio } \\
\text { n and } \\
\text { rubbing } \\
\text { (Pratisara } \\
\text { na) }\end{array}$ & 15 days \\
\hline
\end{tabular}

\section{Pathya-Apathya:}

Patient was strictly advised not to take ice cream, cold drinks, chocolates, fast food, fermented food items, spicy food, or any color chemical containing items. Avoid smoking, faulty voice production and hawking or clearing throat frequently. Patient was advised for cover mouth with mask or clean handkerchief while exposer to dusty and smoky areas, also advised to take steam inhalation through mouth two times a day with plain water. Intake of lukewarm water for the whole day as a routine.

\section{RESULTS: See Table No. 2}

Figure 2: 14 days- congestion and size

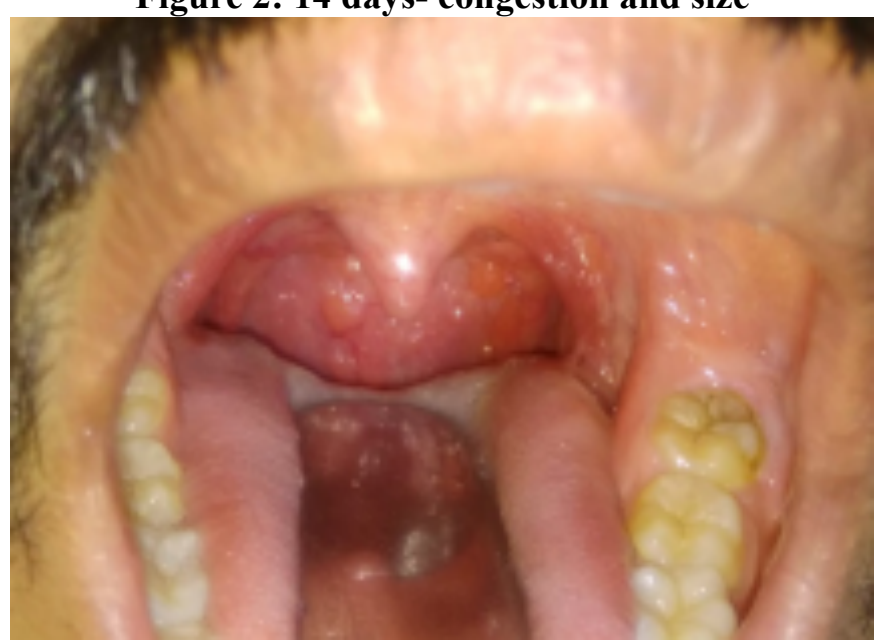

Figure 3: 1 month- granules disappeared reduced after 14 days of treatment

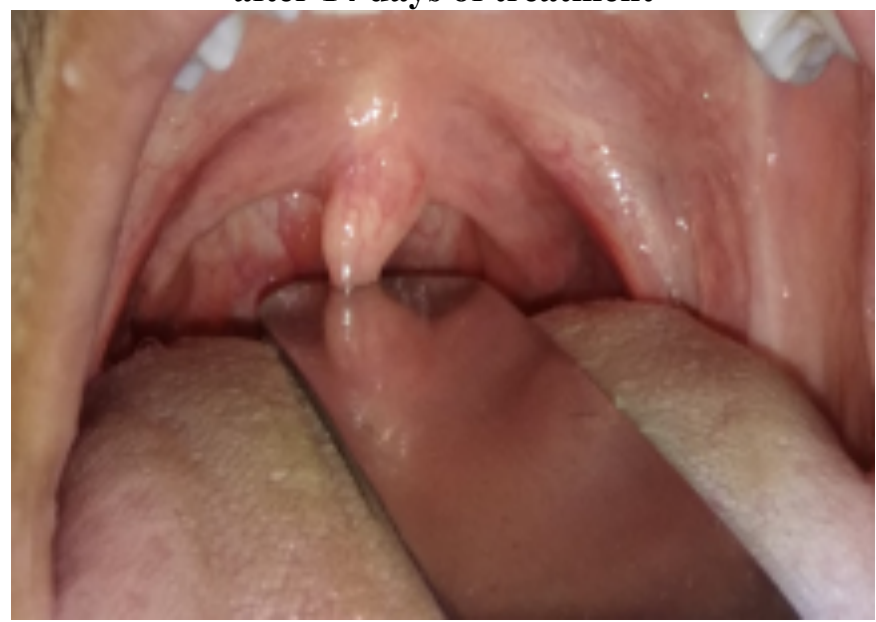


Table: 2 Result

\begin{tabular}{|c|c|c|}
\hline Duration & Result & Pharyngoscopy \\
\hline $\begin{array}{l}7^{\text {th }} \text { day of } \\
\text { treatment }\end{array}$ & $\begin{array}{l}\text { Mild relief in } \\
\text { symptoms. } \\
\text { Frequency of dry } \\
\text { cough and } \\
\text { rhinorrhea mildly } \\
\text { decreased. Relief in } \\
\text { dry and sore throat, } \\
\text { patient was able to } \\
\text { perform his routine } \\
\text { work properly. }\end{array}$ & $\begin{array}{l}\text { Mild } \\
\text { improvement in } \\
\text { congestion but } \\
\text { there was no any } \\
\text { improvement in } \\
\text { size of follicles }\end{array}$ \\
\hline 15 days & $\begin{array}{l}\text { Significant } \\
\text { improvement in all } \\
\text { symptoms. Patient } \\
\text { was able to swallow } \\
\text { semisolid pungent } \\
\text { items easily. }\end{array}$ & $\begin{array}{l}\text { Congestion of } \\
\text { pillars and PPW } \\
\text { was decreased } \\
\text { moderately, } \\
\text { decreased the size } \\
\text { of follicles on } \\
\text { PPW [Image 2] }\end{array}$ \\
\hline 21 days & $\begin{array}{l}\text { Complete relief in } \\
\text { dry cough, } \\
\text { rhinorrhea. Almost } \\
\text { relief in dry, sore } \\
\text { throat and } \\
\text { dysphagia. Able to } \\
\text { swallow solid and } \\
\text { pungent taste items } \\
\text { easily and } \\
\text { comfortable with } \\
\text { frequent talks. }\end{array}$ & $\begin{array}{l}\text { No congestion of } \\
\text { anteroposterior } \\
\text { pillar, tonsils and } \\
\text { P P W, further } \\
\text { decreased the size } \\
\text { of follicles over } \\
\text { PPW. }\end{array}$ \\
\hline 1 month & $\begin{array}{l}\text { patient was quite } \\
\text { satisfied since } \\
\text { patient was } \\
\text { completely relieved } \\
\text { from disease. }\end{array}$ & $\begin{array}{l}\text { Normal throat and } \\
\text { absent the } \\
\text { follicles [Image 3] }\end{array}$ \\
\hline
\end{tabular}

\section{Discussion}

Inhalation of dusty air, smoke and fragrance of seasonal flowers (in autumn season) is more likely to be drawing of dust particles into our nose and mouth and this can act as an irritant. It may result in post nasal drip which constantly irritates the oropharyngeal tissues and ultimately leads to inflammatory changes in the throat. Thus the patient was advised to cover mouth and nose with mask or clean handkerchief while exposer to dusty and smoky areas. Acharya Sushruta mentioned its line of treatment for Kaphaja Rohini as Pratisarana, Nasya and Kavaladharana with Ayurvedic formulations. Massage in a gentle way with tip of the finger for a short duration is called Pratisarana (7).

Acharya Sushruta mentioned that in all Mukhagata Rogas there is predominantly vitiation of Rakta and Kapha Doshas. Yashtimadhu pacifies Rakta Dosha and help soothe the throat through Madhura Rasa and Sheeta Virya properties. Through Pratisarana with honey leads to do Shodhana (decreases the size of follicles) and Ropana of throat. The Yastimadhu powder and extract was found to be effective in treatment of sore throat, cough and bronchial catarrh through decreases irritation and produces expectorant effects (8).
Yashtimadhu mentioned in Kanthya Dshemani so Yashtimadhu Ghanavati was specially indicated for voice and throat disorders (9).

Sitopaladi Churna with Anupana of Madhu has the potential action for cough extraction hence, pacifies Kapha Dosha.

Naradiya Laxmi Vilasa Rasa contains Abhraka Bhasma (10), which has Madhura-Kashaya Rasas with Rasayana and Tridosha Properties. Hence, here it was given for pacification of Kapha Pradhana Tridosha.

When liquid is filled in mouth to such a level that it can be moved easily, is called Kavala (gargles). Dashamoola, a combination of roots of ten plants, have a Ushna Virya is a standard Ayurvedic remedy for inflammatory conditions (11) and reduces mucus production (pacifies Kapha Dosha) also has mucolytic action. Gargles with Dashamoola Kwatha helps in soothe the throat and reduces signs of inflammation, irritation and clear the throat through Swedana effect.

Anti-inflammatory property of the ingredients will reduce the inflammatory process in throat and antibacterial activity arrests the secondary infection and prevents recurrence of the disease. All these factors will ultimately lead to relieve in symptoms of granular pharyngitis. No adverse and toxic effect were observed during the trial and after the treatment.

\section{Conclusion}

This single case report concludes that Ayurvedic management with Kavala, Pratisarana and using internal medicines, i.e., Yashtimadhu Ghanavati, Shitopaladi Churna, Naradiya Laxmi Vilasa Rasa along with proper rest, and steam therapy through mouth offers excellent result in the treatment of chronic granular pharyngitis. This protocol should be evaluated in more number of patients for its scientific validation.

\section{References}

1. Raymond H. Marcotte, XXXVIII Chronic Granular Pharyngitis, annals of Otology, Rhinology \& Laryngology. [Last Accessed on April 25, 2020 Time: 11:20 pm].

2. Scott-Brown's, Scott-Brown's Otorhinolaryngology head and neck surgery, $8^{\text {th }}$ edition, volume 3 , pg.no.802.

3. Dhingra PL \& Shruti Dhingra, assisted by Deeksha Dhingra, Text Book of - Diseases of Ear, Nose \& Throat \& Head \& Neck Surgery, Chapter 49, Acute and Chronic Pharyngitis, Elsevier a division of Reed Elsevier India Private Limited, Reprint edition 2014-2015; 269.

4. Sushruta, Sushruta Samhita, Nidansthana, Mukharoga Nidan Adhyay, 16/52, edited by Dr. Keval Krushna Thakral with Nibandhasangraha commentary of Dalhanacharya and Nyaychandrika commentary of Acharya Gayadasa, Chaukhamba Orientalia, Varanasi, Reprint ed. 2016;891.

5. Sushruta, Sushruta Samhita, Chikitsasthana, Mukharoga Chikitsitam Adhyay 22/63, edited by Dr. Keval Krushna Thakral with Nibandhasangraha commentary of Dalhanacharya and Nyaychandrika 
commentary of Acharya Gayadasa, Chaukhamba Orientalia, Varanasi, Reprint ed. 2016; 410.

6. Sushruta, Sushruta Samhita, Nidansthana, Mukharoga Nidan Adhyay, 16/53, edited by Dr. Keval Krushna Thakral with Nibandhasangraha commentary of Dalhanacharya and Nyaychandrika commentary of Acharya Gayadasa, Chaukhamba Orientalia, Varanasi, Reprint ed. 2016;891.

7. Sushruta, Sushruta Samhita, Chikitsasthana, Dhuma-nasya-kavalgraha Chikitsa Adhyay, 40/70, edited by Dr. Keval Krushna Thakral with Nibandhasangraha commentary of Dalhanacharya and Nyaychandrika commentary of Acharya Gayadasa, Chaukhamba Orientalia, Varanasi, Reprint ed. 2016;625.

8. Jyotsana P.M., A Review on Yashtimadhu (glycyrrgiza glabra)- An Excellent Medicinal Plant for the Future, World Journal of Pharmaceutical Research, Volume 6, Issue 1, Page no. 261-269. [Last Accessed on May 13, 2020, Time: 5 pm].

9. Agnivesh, Charaka, Charaka Samhita, Sutra Sthana, Shadvirechanasatasitiya adhyaya, 4/15, edited by Yadavaji Trikamji Acharya, Reprint ed. Chaukhamba Sanskrit Sansthan, Varanasi. 2005.

10. Padavi DM, Makhijani BM, Study to evaluate the effect of Naradiya Laxmi Vilas Rasa and Goghrita Nasya in the management of vertigo. Jounal of Ayurveda and integrated medical sciences (ISSN 24563110) 2018; 3:5.

11. Shekher Singh, Anti-inflammatory effects of Dashmula, an Ayurvedic preparation, versus Diclofenac in animal models, Journal of Chemical and Pharmaceutical Research. [Last Accessed on May 13, 2020, Time: 12 pm]. 